\title{
The Competencies of Daycare Caregivers in Building Interaction and Attachment with Children to Optimize Their Cognitive Development
}

\author{
Selinna Sandrinia Zainuddin ${ }^{1}$, Ni Made Surianti ${ }^{2}$, Alfiasari ${ }^{3 *}$ \\ ${ }^{1,2,3}$ Department of Family and Consumer Sciences, Faculty of Human Ecology, IPB University, \\ Bogor 16680, West Java, Indonesia
}

*) Corresponding author: alfiasari@apps.ipb.ac.id

\begin{abstract}
Families whose parents are both working have limited time in nurturing their children. This circumstance makes parents, especially mothers, alternate parenting to the babysitter or caring institution called daycare. This study aimed to analyze the correlation of children's characteristics, caregiver-child interaction, and attachment with the cognitive development of preschool children in daycare. This study used a cross-sectional study design with the daycare (TPA) selection as the research location carried out purposively located in the buffer areas of the capital city of DKI Jakarta. Respondents in this study were 39 children aged 2.5-6.4 years with complete parents and 16 caregivers from four selected TPA who interacted with their children daily. Data was collected by means of in-depth observations to measure the interaction variables between caregivers and children. This study indicates a positive correlation between caregiver-child interaction and attachment with a child's cognitive development. This study also found a significant positive relationship between the caregivers-child interaction with caregivers-child attachments and a significant negative relationship between the child's age and the caregivers-child attachment. This shows that interaction, and attachment between caregivers and children are important factors that can improve cognitive development while in TPA.
\end{abstract}

Keywords: attachment, caregiver, cognitive, daycare, interaction

\begin{abstract}
Abstrak
Orang tua yang keduanya bekerja memiliki keterbatasan waktu dalam mengasuh anak. Hal ini menyebabkan orang tua, terutama ibu, mencari alternatif pengasuhan anak pada pengasuh pengganti atau dititipkan di sebuah lembaga yang disebut Tempat Penitipan Anak (TPA). Tujuan penelitian ini adalah untuk menganalisis hubungan karakteristik anak, interaksi dan kelekatan pengasuh-anak dengan perkembangan kognitif anak usia prasekolah di TPA wilayah perkotaan. Penelitian ini menggunakan desain cross sectional study dengan pemilihan TPA yang menjadi lokasi penelitian dilakukan secara purposive berlokasi di wilayah-wilayah penyangga ibukota DKI Jakarta. Responden penelitian ini berjumlah 39 anak berusia 2.5-6.4 tahun dengan orang orang tua lengkap, dan 16 pengasuh dari empat TPA terpilih yang sehari-hari berinteraksi dengan anak. Pengumpulan data dilakukan dengan cara observasi mendalam untuk mengukur variabel interaksi pengasuh dan anak. Hasil penelitian menemukan adanya hubungan positif signifikan antara interaksi dan kelekatan pengasuh-anak dengan perkembangan kognitif anak. Sementara itu, hubungan yang signifikan positif juga ditemukan di antara interaksi pengasuh-anak dengan kelekatan pengasuh-anak serta ditemukan hubungan yang signifikan negatif di antara usia anak dengan kelekatan pengasuh-anak. Hal ini menunjukkan bahwa interaksi, dan kelekatan pengasuh dan anak menjadi faktor penting yang dapat meningkatkan perkembangan kongnitif selama di TPA.
\end{abstract}

Kata kunci: interaksi, kelekatan, kognitif, pengasuh, taman penitipan anak 


\section{Introduction}

In this era of globalization, a person's opportunity to work often no longer considers gender. The rise of issues related to women's emancipation often causes the public's view of a mother who works to earn a living to help increase family income is familiar. An increase in the number of women entering the labour market in urban centres in various countries (Hansen and Hawkes 2009) due to economic factors and high self-actualization has led to a change in the role of women (Puspitawati, 2012). Data from the Central Statistics Agency (BPS) of Province of DKI Jakarta showed that the Labor Force Participation Rate (Tingkat Partisipasi Angkatan Kerja) in women in February 2017 reached 55.85 per cent, increasing from 54.58 per cent. Compare to August 2014, the rate for women was 49.26 per cent and raised in the following year to 50.22 per cent. This fact proves that the number of women in Indonesia who work in the public sector increases every year.

Often, a woman who plays a dual role as wife and mother and the worker will find it difficult to choose between career and family demands (Puspitawati, 2012). In addition, families whose husband and wife work will impact the limited time in caring for and guiding their children. Based on the result of research by Bernal (2008), the characteristics of working mothers relate to cognitive development problems in preschool children. This circumstance is because the growth and development of children happen continuously and simultaneously; it always requires stimulation, response, and direction to create a conducive atmosphere to children's growth and development. The absence of close family or caregivers who can look after children who are still at an early age due to both parents working is a phenomenon that has started to emerge a lot in society, especially in urban communities. Early childhood needs to be cared for properly because children's development at an early age are a critical period in determining the next child's life. One of the stages in the early childhood period is the preschool stage. Preschool-age is the most crucial period in human life (Hastuti, 2015). According to experts, preschool-age is called the golden age in human development, especially in children aged 0-2 years, where children's brain development reaches 70-80 per cent. Children experience positive development in creativity at this stage, have lots of ideas and imagination, dare to try, dare to take risks, and are easy to get along with (Latifah, Krisnatuti, \& Puspitawati, 2016). The phase of preschool-age children to develop their initiative abilities is inseparable from the maturity of their cognitive development. According to Jean Piaget's Theory of Cognitive Development (Santrock, 2007), cognitive development is an aspect of development that emerges and develops rapidly at the preschool age. The initial cognitive potential is formed in the first four years of life.

According to Uce (2017), parents or caregivers who carry out their parenting role optimally for children's growth and development will significantly determine children's intelligence in the future. Thus, children who have better development at preschool-age are determinants of children's success in their next life. At preschool-age, children actively build an understanding of the world. Throughout the child period, four stages of cognitive development occur based on Piaget's theory (Santrock, 2011): the sensorimotor stage, the preoperational stage, the concrete operational stage, and the formal operational stage. The preoperational stage that lasts around 2 to 7 years of age, which is also the most significant part of the preschool period, is cognitive development. Children begin to explain the world with words and pictures (Santrock, 2011). These words and images 
reflect an increase in symbolic thinking and go beyond the connection of sensory information and physical action. Santrock (2007) states that cognitive development in the preschool period makes children to be independent and take care of themselves, develop school readiness skills (follow orders, recognize letters), and spend hours playing with peers.

Cognitive development is influenced by two factors, namely nature and nurture (Santrock, 2007). The nature factor represents a person's biological inheritance, while the nurture factor represents the experience gained by the environment. One example of nurture factors is parents who interact with children and shape how the child's cognitive development (Susanto, 2011). Based on Piaget's theory, humans adapt mentally to their environment through their interactions or experiences with people, objects and events (Santrock 2007). Children's interaction with their parents in early life is an important environmental factor that determines children's development.

One of the risks for working mothers is the lack of time to interact with their children because they have limited time at home. Meanwhile, according to Piaget's theory (Santrock, 2007), children are active students who explore, conduct experiments, and plan to build knowledge. Therefore, when both parents work outside the home, the child needs a replacement caregiver. Caregivers who function as substitute parenting must provide the stimuli needed by the child. Like parents, the stimulus provided by substitute caregivers is also built on the interactions that are built up between substitute caregivers and children. Several alternative institutional care substitutes are available around the community in various forms. One of them is the daycare which is often the primary alternative for families with working mothers (Monika, 2014).

Childcare institutions in Indonesia (also known as Taman Penitipan Anak/TPA) are an alternative place for children to receive a good education and care while their parents are working. The Ministry of Social Affairs first developed TPA in 1963 and then continued by the private sector. According to Hikmah (2014), TPA is the right choice if it can play its role as a 'substitute for parents' in the process of child development in various dimensions, including cognitive development. Therefore, choosing good daycare is one of the alternatives parents must do to optimize children's development, including cognitive development. According to Burchinal, Roberts, Nabors, and Bryant (1996), inadequate daycare institutions become concern issues because infants and preschooler children need responsive and stimulating interactions from caregivers to enhance children's cognitive development. Furthermore, research by Burchinal, Roberts, Riggins, Zeisel, Neebe, and Bryant (2000) stated that the low quality of TPA would result in low achievement of child development.

Thus, daycare can become a good care environment if it has good standards. Some of the standards such as having professional caregivers with the correct ratio of caregivers according to the child's age; a comfortable and attractive place for children; and there is a play area with complete tools to stimulate children's development, such as cubes, balls, pictures, and puzzles (Saputra, Hasanah, \& Sabrian 2015). Meanwhile, according to Berns (2012), the academic performance of children who attend childcare is higher than children from the same family background but do not participate in childcare services. For example, it was shown that children who come from low-income families but attend qualified childcare are more verbally expressive and more interactive with adults than children who do not attend qualified childcare. In addition, Berns (2012) states that preschool children who attend qualified child care can better meet the requirements in 
primary school and function at increasing intellectual capacity during their early school years.

The role of caregivers in TPA is significant in supporting the cognitive development of children. Therefore, like the interaction between parents and children, the interaction between TPA's caregivers and children also plays an important role. For example, Duncan (2003) stated that preschool children need responsive and stimulating interactions with parents and other caregivers to improve children's cognitive development. That way, it is assumed that the interaction between caregivers in TPA and children will affect, considering that most of the children's time is spent with caregivers at the TPA. Furthermore, Halle et al. (2011) stated that building caregiver interactions with children including sensitivity, responsiveness and giving language and cognitive stimulation. Thus, children need interaction from caregivers because, based on Schipper, Marianne, and Geurts (2006), the presence of caregivers to interact with children is very important for children. After all, it provides an essential role in children's development, including cognitive development.

In addition, like the parent-child relationship, one of the critical components in the caregiver-child relationship in TPA is attachment. Attachment is a two-way relationship between caregivers and children that processes slowly and refers to a special bond through the quality of a unique relationship (Hastuti, 2015). The previous study found that children who have a safe attachment to their caregivers show that they can adapt well (Commodari, 2013). The relationship between children and their caregivers in the TPA also demands a similar relationship li kat school. The study results revealed that children who had a safe attachment in their relationship with their preschool teachers impacted most of the children's cognitive skills, such as reading, writing, and mathematics, which were better than children with unsafe attachment (Commodari, 2013). The results of this study emphasize the importance of the relationship between caregivers and foster children in TPA and between teachers and students in quality schools, including safe attachment relationships. Therefore, safe attachment with caregivers will be able to develop children's cognitive abilities. The study results found that children with safe attachment showed a higher score for cognitive development than children with unsafe attachment (Latifah et al. 2016).

Therefore, this research objectives were to identify the characteristics of the child and caregivers, caregiver-child interaction and attachment, and cognitive development of preschool-aged children entrusted to the TPA. Additionally, it also aimed to analyze the relationship between the child's characteristics, the caregiver's interaction and attachment, and the cognitive development of the preschool children entrusted to the TPA. The ability of caregivers in TPA to build interaction and attachment with children is the scope of caregivers' competencies studied in this study.

\section{Methods}

\section{Participants}

This study used a cross-sectional study design. The research locations chosen were representative suburbs of Jakarta, such as Cibubur and several satellite cities (buffer) of Jakarta, such as Bekasi, Tangerang, and Bogor. Jakarta is the centre of government and economic activities in Indonesia. However, the cost of living in this area is quite expensive. The limited space for cheap and decent housing causes residents who work in 
Jakarta to prefer to choose to live in satellite cities, such as Bogor, Depok, Tangerang or Bekasi (BPS 2014).

The socio-economic situation in the satellite city areas continue in line with the economic growth that occurs in Jakarta. The results will have an impact on the socioeconomic condition of the population. One of the impacts of economic changes on changes in the family is the increase in the number of working mothers so that dual-earner families are starting to develop. This change in family-type encourages child care institutions or daycare institutions to grow as partners for parents in caring for children.

This study involved four residential areas as research locations representing Jakarta's representative satellite areas: Cibubur, Bogor, Bekasi, and Tangerang. Each residence has a daycare, so this research conducted in four daycare. The population of this study were preschool children with complete parents who were registered as students in the selected TPA. Therefore, the sample framework of this research is preschool children aged 2.5-6.4 years who are registered as students in the selected TPA. Age 2.56.4 years was chosen as the sample criteria because the age range is the age range in the preoperational stage according to Piaget's Theory of Cognitive Development. The participants in this study included 39 children and 16 caregivers in the four selected TPAs who were willing to become research participants. In addition, this amount is determined according to the permission of the parents. Caregiver participants assume that the number of caregivers and children in the TPA is 1: 2 or 1: 3; that is, one caregiver can care for as many as two to three children.

In the data collection process, the researcher visited each TPA to ask for the willingness to be the research site, then waited for all children involved as research participants to be picked up by their parents and asked permission to become participants. If parents agree, researchers measure the child's cognitive development. Based on this process, of the 94 total populations of the four TPAs, 53 parents met the sample frame criteria, and 39 parents allowed their children to be participants. Therefore, the number of participants in this study were 39 children as participants. Meanwhile, the number of caregivers from the four selected TPAs was 33 people. The caregivers used as participants were 16 caregivers who interacted a day with the sample children in the TPA. The sampling technique used was the nonprobability sampling method using purposive sampling. The data collected in this study are primary data which includes data on child characteristics, caregiver-child interactions and attachments, and cognitive development of children in TPA. Primary data collection through caregiver observation and testing of children's cognitive development.

\section{Measurement}

Data regarding caregiver interactions use the Caregiver Interaction Scale (CIS) instrument developed by Maharta (2017), which uses the concept of Arnett (1989). This instrument is designed to evaluate caregiver behaviour when interacting with a group of preschool-aged children in TPA. This instrument initially used a four-point Likert scale consisting of "not at all" given a score of 1 , "not true" given a score of 2, "slightly correct" given a score of 3 , and "very true" given a score of 4 , then modified by the researcher to become "Never" (1), "sometimes" (2), "often" (3), and "always" (4). This modification was modified by considering that researchers measured caregivers by looking at the frequency of interactions caregivers had in one day. This instrument consists of 26 statements. The caregiver-child interaction data is obtained by observing one caregiver 
with 2-3 children in one day starting at $08.00 \mathrm{WIB}$ to $16.00 \mathrm{WIB}$. The reliability value of the caregiver-child interaction instrument in this study was 0.763 .

The caregiver-child attachment instrument was measured using the Q-Sort instrument, which refers to Vaughn and Water (1990), consisting of 26 statements of children's safe attachment behaviour. Researchers modified 26 Q-sort statements adjusted to children's natural behaviour with their caregivers at the TPA. The use of the Q-Sort instrument supports the description of the safe attachment of the strange situation security classification. It can observe children's attachment based on the situation of the landfill environment, which is made as comfortable as possible as at home in the current study (Vaughn and Water 1990). The results of the observations were grouped into four levels of measurement using a four-point Likert scale $(1=$ never, $2=$ sometimes, $3=$ often, and $4=$ always) with a Cronbach's alpha value of 0.908 .

The cognitive development of preschool-aged children is measured using instruments from the Ministry of National Education (2004). The Ministry of National Education instruments used are instruments with an age range of 2.5 until 3.4-year-olds, 3.5 until 4.4-year-olds, 4.5 until 5.4-year-olds, and 5.5 until 6.4-year-olds. The cognitive development instruments for children aged 2.5 until 3.4-year-olds consist of 6 statements with three answer choices (a scale of zero to two). The instruments for children aged 3.5 until 4.4-year-olds consist of 13 statements with a score range of zero to two on each statement, except for statement number 8 . Statement number 8 has a score range from zero to three. The age instrument 4.5 until 5.4-year-olds and 5.5 until 6.4-year-olds each consisted of 13 statements. However, the 4.5 until 5.4-year-olds age instrument had a score range from zero to three for each statement. Then, the 5.5 until 6.4-year-olds had a score range ranging from zero to two for each statement. The total value of the reliability of cognitive development in this study was 0.856 .

\section{Analysis}

The data obtained were processed through several stages: collecting, editing, coding, entry, scoring, cleaning, analyzing, and interpreting the data. Data processing used Microsoft Office Excel and SPSS software. Before data analysis, scoring data was generated from the interaction and attachment variables of the child-caregiver and the children's cognitive development in the TPA. The scoring results were added up for each of these variables. The total score is then transformed into an index score.

In addition, the variables of interaction and caregiver-child attachment were categorized into three categories, namely; (1) poor: 0-60, (2) good enough :> 60-80, and (3) good :> 80-100. Meanwhile, children's cognitive development is categorized into: (1) low; 0-60, (2) medium :> 60-80, and (3) high :> 80-100. The data analysis method in this research is statistical data analysis, namely descriptive analysis and inferential analysis. Data analysis has been adjusted to the research objectives shown as follows: 1) to identify child characteristics, caregiver-child interaction and attachment, and cognitive development of children entrusted to TPA using descriptive analysis; and 2) to analyze the relationship between child characteristics, caregiver-child interaction and attachment, and cognitive development of children entrusted to TPA using correlation tests. 


\section{Findings}

\section{Characteristics of Childcare and Caregiver}

Data collection in this study was carried out in four selected residencial that are located in urban areas. Then, purposively selected the child care that used a house in selected residencial and have adequate facilities as a location of child care. The fourdaycare had something familiar; the venue was located in the residencial area, like houses not schools, and have a reasonably similar learning curriculum. A similar activity is at 09.00/10.00 a.m. The daycare carried out an activity tailored to the child's level of development and the child's needs by implementing an educational system for playing and learning. The average length of hours for children in daycare until they are picked up is similar, starting from $06.00 \mathrm{a} . \mathrm{m}$; to $06.00 \mathrm{p} . \mathrm{m}$. The facilities provided by the fourdaycare are also generally the same, such as complete play equipment and educational play tools (puzzles and blocks).

The selected daycare located in Cibubur has seven caregivers with 21 children. The selected daycare in Bekasi has nine caregivers with 26 children. In comparison, the daycare in Tangerang area has ten caregivers with 27 children. The selected daycare in the Bogor area has seven caregivers with 20 children. The number of children registered in the selected daycare was 94 children ranging from infants to the second grade of elementary school. The number of children in each daycare averaged 20-27 children.

There are 16 caregivers with an average age of 27 years old from the selected daycare, with the highest proportion of caregivers were junior high school graduates (75\%). Meanwhile, caregivers' average length of worktime experience was 17.63 months, and all of the caregivers in the selected daycare were the first workplace of caregivers. The numbers of caregivers compared to the numbers of children had a 1:2 and 1: 3 . This ratio means that one caregiver is responsible for 2 to 3 children.

\section{Characteristics of Children}

Preschool-aged children in this study consisted of 19 girls with a mean age of 3.8 years old and 20 boys with a mean age of 4.1 years old. In addition, the biggest proportion of children was in the age group 2.5 years to 3.4 years (41\%), followed by the age group 3.5 years to 4.4 years $(35.9 \%)$, then the age group 4.5 years to 5.4 years $(15.4 \%)$ and the smallest proportion was age group 5.5 years to 6.4 years $(7.7 \%)$. Ten of 39 children have been in the daycare for 24 months, with an average of 16.87 months.

\section{The Interaction of Caregiver-Child}

Based on the study results, it was found that 46.2 per cent of caregivers in daycare had interactions with children in the good enough category. The mean index for caregiverchild interactions was 76.16. These outcomes also indicate that the quality of caregiverchild interactions is nearing the upper cut-off limit (index 80.00) as a high interaction parameter. This finding means that overall interactions carried out by caregivers to children are good enough in building positive interactions with children in daycare. Based on the analysis of statements to measure caregiver-child interactions in daycare, the results showed that almost half of caregivers often talked to children happily (48.72\%) and often looked happy with children $(46.15 \%)$. Even so, the challenge of building high caregiver interactions needs to be increased, mainly because of the more significant proportion of caregivers with children $(41.03 \%)$ and caregivers sometimes still talk to children briefly $(30.77 \%)$. Meanwhile, caregivers with poor interaction category were 
12.82 per cent. The study results found that there were caregivers who paid less attention to children's behaviour $(41.03 \%)$ and never encouraged children when they tried new experiences $(64.10 \%)$. In addition, caregivers sometimes did not supervise children well $(38.46 \%)$.

\section{The Attachment of Caregiver-Child}

The study results found that almost half children (43.60\%) could form a relatively safe attachment with their caregivers. One-third of children $(33.30 \%)$ can form a safe attachment, and the rest (23.10\%) form an unsafe attachment. The mean caregiver-child attachment index score was 68.51, with a standard deviation value of 16.53 . The achievement of the caregivers' attachment. It was quite good compared to the cut-off parameter, but it was still close to the low limit.

\section{The Cognitive Development of The Children}

The results showed that preschool children in daycare had a good enough category of cognitive development with an average of 77.55. When viewed from the age group, the highest average was achieved by the 2.5-3.4 year age group with an average of 84.03. Meanwhile, the lowest average was owned by the 3.5-4.4 year age group with an average of 71.45. When viewed based on the child's age, the highest achievement of cognitive development was 2.5-3.4 years old and the lowest was 3.4-4.5 years old. Children aged 2.5-3.4 years can name one to four colours (91.67\%), match red, white, black and brown colours $(83.33 \%)$ and know their name $(100 \%)$, but there are still children who are not able to mention their gender (50\%). Meanwhile, the 3.5-4.4 year age group was able to name $5-9$ colours or more $(58.82 \%)$, arrange the colour pieces according to the pattern $(64.71 \%)$, differentiate the gender of other people $(82.35 \%)$, and pair pictures of objects that they have known (94.12\%). However, there were still children who had not been able to draw a person with their parts $(58.82 \%)$, children could only say their nicknames (64.71\%), and children were correct one to two in asking questions to get information using the questions "why" and " how "(52.94\%).

\section{The Correlation of Child Characteristics, Caregiver-Child Interaction, and Caregiver-Child Attachment}

The correlation test results presented in Table 1 indicate a negative relationship between the characteristics of the child's age and caregiver-child attachment. These findings indicate that the older the child is, the lower the caregiver's safe attachment isthis fact supported by the low category of caregivers' attachment to older children. Item analysis of questionnaire showed the distribution of answers never seen inviting caregivers to play with the expected response they want, never showing the behavior of sharing affection with caregivers and never showing an attitude as if they wanted to cry when the caregiver leaves. In addition, there is a positive relationship between caregiver interactions with caregiver attachment (Table 1). This finding means that the more interactions the caregiver have with the child, the closer interaction between the caregiver and the children.

\section{The Correlation of Caregiver-Child Interaction, Caregiver-Child Attachment, and Cognitive Development of The Children}

The results presented in Table 1 also show a significant positive relationship between caregiver-child interaction and attachment with children's cognitive 
development in daycare. This research found a significant positive relationship between caregiver interactions and children's cognitive development with a coefficient of $r=0.351$ $(\mathrm{p}<0.05)$. This finding shows that the better the caregiver-child interaction, the higher the cognitive development of the child. In addition, this research also found a significant positive relationship between caregiver attachment and children's cognitive development with a coefficient of $r=0.351$ ( $p<0.05)$. These results indicate that the safer the attachment between caregiver and child, the better the child's cognitive development in daycare. These findings indicate that caregivers in daycare who can build good interactions and safe attachment with children will increase children's cognitive development.

Table 1 Correlation coefficients of child characteristics, caregiver-child interactions, caregiver-child attachment, and children's cognitive development

\begin{tabular}{lccc}
\hline Variable & $\begin{array}{c}\text { Caregiver-child } \\
\text { interaction }\end{array}$ & $\begin{array}{c}\text { Caregiver-child } \\
\text { attachment }\end{array}$ & $\begin{array}{c}\text { Cognitive development } \\
\text { of the children }\end{array}$ \\
\hline $\begin{array}{l}\text { Child's age (years) } \\
\begin{array}{l}\text { Length of time in } \\
\text { daycare (months) }\end{array}\end{array}$ & -0.105 & $-0.405^{*}$ & 0.006 \\
$\begin{array}{l}\text { Caregiver-child } \\
\text { interaction }\end{array}$ & -0.173 & 0.076 & 0.129 \\
$\begin{array}{l}\text { Caregiver-child } \\
\text { attachment }\end{array}$ & 1 & $0.376^{*}$ & $0.351^{*}$ \\
Note: *Significant on $\mathrm{p}<0.05$ & - & 1 & $0.351^{*}$ \\
\hline
\end{tabular}

\section{Discussions}

The caregiver-child interaction is a reciprocal relationship between caregivers in daycare in their approach to children, such as talking to them or inviting them to play. Since birth, the relationship between children and adults is significant in determining children's healthy social and emotional development. It serves as a mediator for language and intellectual/cognitive development (Carl, 2007). The interaction of caregivers in daycare with children can be seen from the caregiver's sensitivity to the cues given by the child, such as paying attention to children's interests, desires or opinions; always full of affection; creates a sense of security and comfort; set an example without being pushy; encourage the courage to try to be creative; and give awards or praise for success or good behavior (Handayani, 2014). The results of this study found that the interaction between caregivers and children was categorized as quite good, with an average index score of 76.16. This good enough interaction can occur because the ratio of caregivers to children is between 1: 2 and 1: 3 so that the quality of caregivers' interactions with children runs optimally. Although the quality of this interaction still needs to be improved. Training for caregivers to recognize the dimensions of caregiver-child interaction and ways to improve it needs to be done to increase the competence of caregivers. Moreover, this study found a significant positive relationship between caregiver-child interactions with the cognitive development of preschool children in the daycare of the study location.

These findings are in line with the research of Schipper et al. (2006), which states that caregivers with fewer children in their care will be more sensitive, responsive, warm, and encouraging to children. These aspects are important factor in providing good interactions with children. In addition, some caregivers always want to be close to children (58.97\%), caregivers do not manage the children much (69.23\%), caregivers like 
to talk to children (79.48\%), caregivers do not try to control children with punishment (94.87\%), and caregivers give positive attention to children as individuals $(84.61 \%)$. Based on in-depth observations of interactions made by caregivers on the statement "giving positive attention to children", namely smiling at children, making eye contact and using caring facial expressions, showing interest in children's activities by using interesting language. In addition, the statement "the caregiver likes to talk to the child" is like the caregiver often asks the child, talking to the child by asking what the child is doing (pointing at what color, what picture). Thus, if the caregiver's interaction is carried out properly and correctly, the child will feel safe and comfortable in his condition in the daycare and the child will have more confidence in what he is doing. As Blegur, Fatimah, and Aminah (2014) stated, the role of caregivers is to invite children to talk, play interactive games, give children the right to express opinions, and be given the freedom to determine what is best for them. The role of interaction on child development is also found in this study, showing that the better the interaction between caregivers and preschool children in daycare, the better cognitive development. This finding is in line with the NICHD Early Child Care Research Network (2000) study, which found that caregiver interactions with children are associated with the cognitive development of preschool children. This association is because the environment is verbally stimulating to child development. The NICHD Early Child Care Research Network (2000) states that a child care environment characterized by verbal supportive and stimulating caregiver interactions improves children's performance.

The interaction of children with adults is vital in improving the cognitive development of preschoolers (Santrock 2007). Duncan (2003) stated that infants and preschool children need responsive and stimulating interactions with parents and other caregivers to promote social, cognitive, and language development in early childhood. The interaction of caregiver-children is characterized by frequently inviting children to talk, approaching children while playing, and paying attention to children's behavior affecting children's cognitive development. Duncan (2003) states that children's cognitive outcomes involve interaction with adults characterized by talking a lot, focusing attention on children, and teaching children to explore.

Meanwhile, caregiver attachment to the child in this study refers to the emotional bond between caregiver and child. This bonding can be seen from their behavior that feels safe with their caregiver. Attachment refers to a special or special bond characterized by a unique relationship between mother and child or between caregiver and child in her care and vice versa through a slow process (Hastuti, 2015). In this study, the attachment seen was the safe attachment of the child to the caregiver in daycare. The safe child's attachment to their caregiver is indicated by the child having a desire to be close to his attached figure, especially in a state of fear or pressure. Additionally, the child feels safe and comfortable with his attached figure to dare to explore his environment, and the child shows an anxious attitude when the attached figure leaves (WHO, 2004).

The formation of attachment to the attached figure, the child will go through a specific process. According to Bowlby in Cenceng (2015), there are four phases of attachment stages. First, it is known as Phase 1 (from birth to 3 months of age). An indivisible response to humans characterizes this phase. Babies will respond to various responses to the people around them, such as smiling and chattering to everyone, which can trigger a baby's closeness to their attached figure. Next is Phase 2 (from 3 to 6 months of age), focusing on the people they know, i.e. babies begin to limit their interactions with people they know, and babies develop the strongest attachment to their sensitive 
attachment figures in interacting with themselves. In Phase 3 (from 6 months to 3 years), the intense attachment and the search for closeness are active, i.e. attachment with the attached figure becomes more intense. At the age of 6 months, it seems that the baby will cry when the sticky figure is left behind and will hug the sticky figure when he returns. At seven months of age, babies begin to show fear of strangers. At eight months of age, babies begin to crawl to follow where their attached figures go. Then at the age of 3 years, the child will have a specific attached figure. Finally, in Phase 4 (from 3 years of age to the end of the child's life), attachment is characterized by friendly behavior. The child begins to understand how to form relationships with the people around him when his attached figure leaves.

The results of this study found a significant positive relationship between caregiver attachment and cognitive development of preschool children in daycare $(r=0.351 ; \mathrm{p}$ $<0.05$ ). In particular, children who have safe attachment have better language levels and psychomotor abilities (attention and meta-cognition) and cognitive abilities (e.g. reading, writing and mathematics) than children with unsafe attachment (Commodari, 2013). As a substitute figure of attachment, the caregiver can create a reasonably safe attachment to the child. The results of this study are consistent with the research of Latifah et al. (2016), which states that grandmothers as a substitute for working mothers can create a safe attachment for children so that they have a positive effect on children's cognitive development. Therefore, caregivers in this study who can build a safe attachment with children will positively impact children's cognitive development. This study has limitations in using the purposive sampling method to see the cognitive development of preschool children and the factors related to or affect children's cognitive development in daycare selected in this study.

\section{Conclusion and Recommendation}

\section{Conclusion}

In this study, the cognitive development of preschool-aged children in the four selected daycare shows moderate development with an average index score of 77.5. The interaction between caregivers and children shows a reasonably good interaction with an average index score of 76.1. Meanwhile, the caregiver-child attachment was in a good enough category with an average index score of 68.51 . The correlation test results show that the more caregiver-child interactions are positively related to caregiver-child attachment, meaning that the more interactions that caregivers make, the more caregivers can be with the child. In addition, there is a relationship between the interaction and attachment of daycare caregivers with the cognitive development of children in daycare. Therefore, both the interaction and caregiver-child attachment are essential factors that can improve children's cognitive development during daycare.

\section{Recommendation}

The interaction of adults (daycare caregivers) with children is significant for children's development. Based on the results of this study, caregiver interactions affect the cognitive development of preschool-aged children in daycare. The caregiver-child interaction can be improved by providing education carried out by daycare parties, especially on how to convey messages or communicate to children properly. A briefing can be held every morning to get used to the excellent way of interacting. In addition, the 
caregivers should refresh the daycare atmosphere every day to build positive interaction with the children.

In addition, daycare is also expected to provide training to its staff, especially caregivers, to build a safe attachment between children and caregivers, as caregivers begin to be trained on responding to children responsively and sensitive to the needs of children around them. Future research is expected to examine other factors that can influence children's cognitive development, such as examining mother-child interactions at home. Moreover, future research can measure a more comprehensive range of child development, such as fine and gross motor skills, social emotions, and language.

\section{References}

Bernal, R. (2008). The effect of maternal employment and child care on children's cognitive development. International Economic Review, 49(4),1173-1209.

Berns, R. (2012). Child, family, school, community: Socialization and support. Nelson Education. Eight edition.

Blegur, L., Fatimah, \& Aminah. (2014). Pola asuh dan perkembangan anak ditempat penitipan anak. Pediatric Nursing, 1(1), 5-8.

Badan Pusat Statistik. (2014). Survei Komuter Jabodetabek 2014. Jakarta (ID) : Badan Pusat Statistik.

Badan Pusat Statistik. (2016). Indikator Pasar Tenaga Kerja Indonesia 2016. Jakarta (ID): Badan Pusat Statistik.

Badan Pusat Statistik. (2017). Keadaan angkatan kerja di Idonesia Februari 2017. Katalg BPS No. 04120.1702.ISSN.0126-647X.

[BPS DKI Jakarta] Badan Pusat Statistik Provinsi DKI Jakarta. (2017). Keadaan ketenagakerjaan di DKI Jakarta Februari 2017. Berita Resmi Statistik No. 27/05/31/Th.XIX.

Bronfenbrenner, U. (1979). The Ecology of Human Development: Experiments by Nature and Design. UK: Harvard University Press.

Burchinal, M. R., Roberts, J. E, Nabors, L. A., \& Bryant, D. M. (1996). Quality of center child care and infant cognitive and language development. Child Development, 67,606-620.

Burchinal, M. R., Roberts, J. E., Riggins, J. R., Zeisel, S. A., Neebe, E., \& Bryant, D. (2000). Relating quality of center-based child care to early cognitive and language development longitudinally. Child development, 71(2), 339-357.

Carl, B. (2007). Child caregiver interaction scale. [Dissertation]. Indiana University of Pennsylvania.

Chlid and Youth Studies Group The Open University. (2007). Attachment Relationships : Quality of care for Young Chindren. Dalam Woodhead M dan Oates J (Ed). United Kingdom (UK) : The Open University

Commodari, E. (2013). Preschool teacher attachment, school readiness and risk of learning difficulties. Early childhood research quarterly, 28, 123-133.

Duncan, G.J., \& National Institute of Child Health and Human Development Early Child Care Research Network. (2003). Modeling the impacts of child care quality on children's preschool cognitive development. Child Development, 74(5), 1454-1475.

Halle, T., Anderson, R., Blasberg, A., Chrisler, A., \& Simkin, S. (2011). Quality of Caregiver-Child Interactions for Infants and Toddlers (QCCIIT): A Review of the 
Literature. Washington, DC: US Department of Health and Human Services, OPRE.

Handayani, S. P. (2014). Pola pengasuhan anak pada taman penitipan anak 'Aisyiyah Wilayah Riau. Jurnal Online Mahasiswa (JOM), 1(2), 1-15.

Hastuti, D. 2015. Pengasuhan: teori dan prinsip aplikasinya di Indonesia. Bogor. Institut Pertanian Bogor.

Hikmah, S. (2014). Optimalisasi perkembangan anak dalam day care. Jurnal Sawwa Studi Gender, 9(2), 345-360.

Latifah, E. W., Krisnatuti, D., \& Puspitawati, H. (2016). Pengaruh pengasuhan ibu dan nenek terhadap perkembangan kemandirian dan kognitif anak usia prasekolah. Jurnal Ilmu Keluarga dan Konsumen, 9(1), 21-32.

Maharta, R. P. (2017). Hubungan Interaksi Pengasuh dengan Personal Sosial Anak Usia 3-5 Tahun di TPA Pelangi Anak Negeri dan TPA Happy Bear Group Yogyakarta. Skripsi. Yogyakarta(ID): STIKES Jenderal Achmad Yani Cimahi

Monika, S. (2014). Motivasi orang tua menitipkan anaknya di daycare. Provitae Jurnal Psikologi Pendidikan, 6(1), 38-57.

National Institute of Child Health and Human Development Early Child Care Research Network. (2000). The relation of child care to cognitive and language development. Child Development, 71(4), 960-980.

Santrock, J. W. (2007). Psikologi Pendidikan. Ed 2. Jakarta : Prenada media Group.

Santrock, J. W. (2011). Perkembangan Anak. Ed 11(1). Jakarta : Erlangga.

Saputra, F., Hasanah, O., \& Sabrian, F. (2015). Perbedaan tumbuh kembang anak toddler yang diasuh orang tua dengan yang dititipkan ditempat penitipan anak (TPA). JOM. 2(2), 1123-1130.

Schipper, E. J., Marianne, R. M. J., \& Geurts, S. A. (2006). Effects of child-caregiver ratio on the interactions between caregivers and children in child-care centers: an experimental study. Child Development. 77(4), 861-874.

Susanto, A. (2011). Perkembangan Anak Usia Dini: Pengantar dari berbagai Aspeknya. Jakarta (ID): Kencana.

Yuliastanti, T. (2013). Keberhasilan bounding attachment. Jurnal Kebidanan, 5(02):8.

Uce, L. 2017. The golden age: masa efektif merancang kualitas anak. Bunayya: Jurnal Pendidikan Anak, 1(2), 77-92. 